\title{
Effective Digital Channel Marketing for Cybersecurity Solutions
}

\author{
Mika Westerlund and Risto Rajala
}

\author{
"Why kick the man downstream who can't put the") \\ parts together because the parts really weren't \\ designed properly?
}

Philip Caldwell (1920-2013)

Former CEO of the Ford Motor Company

\begin{abstract}
Smaller organizations are prime targets for hackers and malware, because these businesses lack cybersecurity plans and the resources to survive a serious security incident. To exploit this market opportunity, cybersecurity solution providers need to leverage the power of downstream channel members. We investigate how a supplier's digital channel marketing can encourage value-added resellers to sell that supplier's cybersecurity solutions. Our analysis of survey data from 109 value-added resellers of a multinational supplier shows that resellers are more committed to stock and sell cybersecurity products and services if the supplier's digital channel marketing provides tools that help them sell the solutions to end customers. This support is likely needed because cybersecurity offerings are technologically complex and systemic by nature, as supported by the finding that value-added resellers pay little attention to supplier's campaigns and price discounts. Thus, cybersecurity suppliers should maintain trusted and informative relationships with their resellers and provide them with hands-on sales tools, because a reseller's commitment to selling cybersecurity solutions is linked with their ability to understand the offering and with the extent of their supplier relationship. These findings are in line with previous literature on the challenges perceived by salespeople in selling novel and complex technology.
\end{abstract}

\section{Introduction}

According to The 2112 Group (2014), the volume and severity of cyber-threats and malware represent the second highest operational risk for small and midsized businesses, behind only economic uncertainty. Yet, four out of five such businesses have no cybersecurity plans, meaning there is a substantial market opportunity for cybersecurity providers. One of the most effective ways to reach these numerous potential customers is to leverage the power of downstream channels (cf. Sreenivas \& Srinivas, 2008; Chung et al., 2012). Valueadded resellers are systems integrators that can work either with a single vendor that offers most of the technology needed to build end-to-end offerings, or multiple vendors to integrate and craft more comprehensive solutions. Although many value-added resellers prefer working with a single vendor, a growing number show better returns by creating holistic solutions using multiple "best-of-breed" technologies (The 2012 Group, 2014). Given that value-added resellers have choices in sourcing, assembling, and deploying hardware and software solutions for customers, cybersecurity suppliers need to build brand awareness to maximize the popularity of their products as a part of the reseller's total solutions.

Digitization has redefined how contemporary businesses communicate across their channels of distribution (Rapp et al., 2013). Holden-Bache (2011) refers to a study by BtoB Magazine in which more than 93 percent of business-to-business marketers were found to use 


\section{Effective Digital Channel Marketing for Cybersecurity Solutions}

\section{Mika Westerlund and Risto Rajala}

one or more forms of social media to interact with their downstream channel members. According to Kalyanam and Brar (2009), designing a channel-management system that enables value-added resellers to sell solutions to end users is an important strategy, particularly in the information and communication technology industry. Furthermore, Jerman and Zavrsnik (2012) suggest that the success of an organization can result from the effectiveness of its marketing communication. Hence, a firm should have a business model that tracks how marketing communication influences what its customers know, believe, and feel, and how they behave.

Much of the current research on downstream channel marketing focuses on value propositions associated with products or services. In addition, many studies on marketing communications have focused on the consumer market, with little regard for the business-tobusiness market (Jerman \& Zavrsnik, 2012). The determinants of perceived value associated with complex products and services, such as cybersecurity, remain unclear and largely under-explored (Menon et al., 2005). Hence, the existing literature offers limited empirical and theoretical insight into marketing communications effectiveness in business-to-business marketing. Specifically, there is little help for marketing managers when planning effective communications strategies and understanding the impact of their suppliers' channel marketing activities (Jerman \& Zavrsnik, 2012).

To address these gaps in the literature, we investigate the effectiveness of digital channel marketing in the context of business-to-business cybersecurity solutions. We consider that cybersecurity is an interesting context given the growing demand for cybersecurity solutions, especially among small and midsized businesses, and acknowledge that the marketing activities of suppliers in downstream channels are increasingly digital by nature. Craigen and colleagues (2014) define cybersecurity as "the organization and collection of resources, processes, and structures used to protect cyberspace and cyberspace-enabled systems from occurrences that misalign de jure from de facto property rights." Bearing this definition in mind, our study aims to improve the current understanding of how cybersecurity solution providers can increase the impact of their digital channel marketing by focusing on the paramount marketing activities and by allocating their marketing resources accordingly. Further, our study draws on the view of Johanson (2013), who defines cybersecurity products as software, hardware, and ser- vices that help users protect themselves from cybersecurity threats related to information sharing, security risks, cyber-incidents, and cybercrime, as well as cyberintrusions. Thus, we investigate cybersecurity solutions as the offerings consisting of products and related expertise provided to meet the customers' cybersecurity needs and posit a research question: How can suppliers of cybersecurity solutions use digital channel marketing effectively to promote their products in the downstream channel?

To answer our research question, we investigate the effects of digital channel marketing by cybersecurity solution providers in terms of its functional, informative, and relational qualities, as well as the influence of marketing abundance on the effectiveness of digital channel marketing by cybersecurity solution providers. According to Kalyanam and Brar (2009), there are many ways in which channel partners such as resellers can help generate demand. Resellers are often deeply embedded in the customer's decision-making processes and are able to create and offer solutions to customer's specific business situation and technology needs. Thus, suppliers need to focus on creating top-of-mind awareness among their value-added resellers to ensure them becoming a preferred supplier when resellers are in a position to sell cybersecurity solutions to the end customers.

The article is structured as follows. After this introduction, we discuss the objectives and activities of digital channel marketing on the basis of prior literature. Then, we present our research model and methodological approach. Thereafter, we present the results, limitations, and future research opportunities regarding our empirical inquiry. We conclude by discussing the implications for research and practice.

\section{Digital Channel Marketing}

A supplier's success in the marketplace is at least partly contingent on their ability to energize downstream channel members to resell their products and services, according to Hughes and Ahearne (2010). Moreover, Danaher and Rossiter (2011) argue that digital marketing communication is a vital part of the relationship between a supplier and a value-added reseller. Contemporary marketers face an increasingly wide and diverse choice of digital media channels through which they aim to energize their brokers, agents, wholesalers, and retailers to sell their products and services effectively to other channel members, and, ultimately, to the end 


\section{Effective Digital Channel Marketing for Cybersecurity Solutions}

\section{Mika Westerlund and Risto Rajala}

users. As Internet technologies have become an everyday part of the workplace for millions of people around the globe, current marketing channels feature many digital elements such as banner ads, email and blogs, social software, and text messaging (SMS). Lindgreen and colleagues (2006) show that many suppliers increasingly use digital communications to interact with their resellers rather than face-to-face interaction.

To be effective, channel marketing communications should create value for channel partners. According to Simpson, Siguaw, and Baker (2001), the objective of creating value for channel partners and the desire to capture part of that value are the reasons suppliers enter into relationships with value-added resellers. Barry and Terry (2008) point out that the determinants of value have an economic, technical, and functional dimension. Economic value refers to pricing (how much something costs), while technical value points to deliverables (what is received) and functional value refers to delivery (how it is received). Payne and Holt (2001) argue that, according to the augmented product view, competition between companies is not based solely on products and services, but also on advertising and customer advice that create value for the downstream channel members. Edwards, Battisti, and Neely (2004) anticipate that the benefits of digital channel marketing for value-added resellers depend upon the quality and extent of activities the supplier generates through digital marketing. The benefits of digital channel marketing may be realized by communicating the value of factors beyond the core product or service (Lilien et al., 2010).

The effectiveness of marketing communications can be measured in several ways, although in terms of economic measures, the most common indicator of marketing performance is the volume of sales. Danaher and Rossiter (2011) investigate supplier-initiated marketing communication and measure the effect of promotional offers in an electronic medium on intentional customer behaviour. Thus, marketing effectiveness in supply chains can be measured as the reseller's intention and increased efforts to sell a supplier's products and services (Johnson et al., 2001). Kalyanam and Brar (2009) found that, because resellers in the dynamic information technology industry are typically selling many technologies, they lack the time to focus and learn specific technologies or product information. Following Jerman and Zavrsnik (2012), we see that it is important for marketers to understand the contribution of different marketing objectives to the overall effectiveness of their marketing communications.

\section{Relational qualities}

The relational qualities of digital channel marketing focus on strengthening the supplier's relationships with the members in the downstream channel. This notion is concordant with the thesis by Webster (2000), according to which, in the relationship between the supplier, reseller, and end customer, the quality of the relationship for any given actor will depend on the quality and strength of the relationship between the other two actors. The value of the supplier relationship, as perceived by the reseller, usually refers to the net benefits realized through the supplier's offerings or the supplier-reseller relationship (Kumar et al., 1992). It builds on the assumption that value-added resellers want to maximize the perceived benefits and minimize the perceived sacrifices (Lindgreen \& Wynstra, 2005). A supplier's business marketing communications have great potential to produce such value to the value-added reseller. According to Andersen (2001), marketing communication is connected with relationship development, and the receiver's commitment to the sender is preceded by awareness and persuasion.

Relationship marketing scholars have found that communication is a fundamental aspect of relationship development - it is the glue that holds together the channel of distribution (Anderson, 2001). Andersen also notes that communication has a direct impact on central aspects of relationship marketing such as trust, coordination, and commitment. Communication is seen as an independent or mediating variable for partnership success (Mohr \& Spekman, 1994). The essence of these activities is to decrease exchange uncertainty and to encourage customer collaboration and commitment through gradual development and ongoing adjustment of mutual norms and shared routines. If customers are retained over several transactions, both buyers and sellers may profit from the experience gained through previous transactions (Andersen, 2001). Accordingly, we developed the following hypothesis:

\section{Hypothesis 1: Digital channel marketing that strengthens the relationship between supplier and value-added reseller is positively linked with the re- seller's intention to sell the supplier's cybersecurity solutions.}

\section{Informative qualities}

The informative qualities of channel marketing ensure that value-added resellers are kept up to date with campaigns and product developments. Jerman and Zavrsnik (2012) posit that marketing communications 


\section{Effective Digital Channel Marketing for Cybersecurity Solutions}

\section{Mika Westerlund and Risto Rajala}

aimed at downstream channel members play more of an informational and supportive role than do those that target end consumers. Marketing communications need to provide clear, pertinent, and timely information, so that good decisions can be made (Jerman \& Zavrsnik, 2012). Hansen and colleagues (2008) suggest that information sharing increases the value of the supplier-reseller relationship, as perceived by the value-added reseller, and it fosters adaptation and trust in that relationship. Moreover, Edwards, Battisti, and Neely (2004) found that suppliers can be a key source of information for buyers, exceeded only by the company's internal knowledge acquisition. Hansen, Samuelsen, and Silseth (2008) point out that suppliers may inform their value-added resellers about the product-related information relevant for the relationship, including changes in pricing, changes in market, new products and services, as well as organizational changes that may affect the supplier-reseller relationship. In particular, sales promotion is an informative type of communication that consists of a set of short-term motivational tools used to encourage buyers to buy more and promptly (Rahmani et al., 2012).

According to Kalyanam and Brar (2009), high-tech companies such as Cisco, which has invested significantly in digital channel marketing, training, and certification programs for its downstream channel members, have enjoyed increased sales volumes. Therefore, Simpson, Siguaw, and Baker (2001) argue that the supplier's activity as a provider of information can serve as a critical informational resource for the reseller. One-way oriented communication, such as advertising, branding, and other traditional tools, may help the supplier develop an attractive personality profile (Andersen, 2001). Hence, if a supplier has developed an attractive image in the mind of the prospective buyer, it may cause the decision maker to look for information on this particular supplier first: a top-of-the-mind effect (Andersen, 2001). Hence, we developed the following hypothesis:

Hypothesis 2: Digital channel marketing that is informative of supplier's campaigns and price discounts is positively linked with the reseller's intention to sell the supplier's cybersecurity solutions.

\section{Functional qualities}

Functionally motivated communication supports the capability of downstream channel members to resell the suppliers' products. For example, suppliers may possess specific expertise, which the downstream channel partners may not have in-house or may not want to acquire (Ulaga, 2003). This benefit is especially important with complex technology such as cybersecurity products and services. Therefore, a supplier of cybersecurity products can provide benefit to value-added resellers by educating and helping them improve their skills and competences to sell the supplier's products. Supplier-provided facilities and tools are among the key factors that augment the value perceived by downstream channel partners (Simpson et al., 2001). In addition, Simpson, Siguaw, and Baker (2001) contend that product and service related training is perceived valuable by resellers. These tools include point-of-sale scanner data for inventory, promotion and payment management, customer management database tools, and an online presence for Internet marketing. According to Simpson and colleagues (2001), research has shown that these supplier-provided tools improve the sales performance of value-added resellers. Also, Lindgreen and colleagues (2006) suggest that the value of channel marketing goes beyond the immediate value of goods or services, given that the education the supplier provides is part of that value.

We consider the functional objectives to be instrumental by nature, because the supplier helps its value-added resellers obtain something to improve their sales performance. In doing so, we comprehend the instrumental value of suppliers' digital channel marketing through two distinct aspects. First, it implies that value-added resellers perceive the digital marketing communications of their suppliers as useful, because it helps the resellers to develop and improve their selling skills and capabilities. Second, it gives the resellers new tools for selling complex products and services. Based on these notions, we consider it reasonable to suggest that digital channel marketing by suppliers can support resellers by providing them with professional skills or practical tools that improve their sales performance. Therefore, we developed the following hypothesis for the context of cybersecurity:

Hypothesis 3: Digital channel marketing that provides functional support to resellers is positively linked with the resellers' intention to sell the supplier's cybersecurity solutions.

\section{Abundant digital channel marketing, sales intention, and stocking decisions}

Previous research does not consistently show whether more digital marketing is better from the performance point of view. There may be a valuable premium in frequency and continuity of marketing messages to the 


\section{Effective Digital Channel Marketing for Cybersecurity Solutions}

\section{Mika Westerlund and Risto Rajala}

customers. Danaher and Rossiter (2011) researched how customers perceive marketing communications and direct marketing messages they receive from suppliers in various ways, including different channels. Surprisingly, senders rate email more negatively than receivers do. That is, business receivers view email messages in a positive light, but senders are more cautious in fear of using it excessively. Thus, it makes sense, for instance, to send multiple waves of marketing emails, because marketers in the digital era cannot count on the recipients to open a particular email message. Consequently, we developed the following hypothesis:

\section{Hypothesis 4: Abundant digital channel marketing is positively linked with reseller's intention to sell the supplier's cybersecurity solutions.}

The theory of reasoned action developed by Fishbein and Ajzen (1975) and its successor, the theory of planned behaviour proposed by Ajzen (1985), are among the most predictive persuasion theories. They have been applied to studies of the relations among beliefs, attitudes, behavioural intentions and behaviours in various fields such as advertising, public relations, and marketing. The theory states that behavioural intention, which is a function of attitudes toward behavioural and subjective norms toward that behaviour, predict actual behaviour. Thus, we developed the following hypothesis:

Hypothesis 5: The intention of value-added resellers to sell a supplier's cybersecurity solutions is positively linked with its stocking decisions.

\section{Model}

Our research model is rooted in previous studies on the effectiveness of advertising on sales performance. One of them is the article by Hughes (2013) about the effects of advertisement on sales efforts and performance of resellers. Jerman and Zavrsnik (2012) confirm that marketing communications have a positive effect on the market performance of suppliers. With increasing calls for accountability of significant marketing communication spending, it is imperative to measure the contribution of marketing communication to firm performance (Jerman \& Zavrsnik, 2012).

Lemmink and colleagues (1998) have proposed that customer value includes emotional, logical, and practical benefits. We amend their conceptualization for a better fit with channel marketing in supply chains, and anticipate that the supplier's digital channel marketing provides resellers with relational, informative, and functional benefits. These benefits comprise the perceived quality of digital channel marketing, whereas marketing abundance, referring to the extent and volume of marketing messages, reflects the quantity of marketing. In our research model, sales intention refers to a reseller's increased effort to sell the supplier's products and the reseller's stocking decision is understood as the actual purchase of the supplier's products to ensure its stock-and-sell availability. As the hypothesized model illustrates, we anticipate that both quality and quantity of a supplier's digital channel marketing contribute to the sales intention of its value-added resellers, and, ultimately, to their stocking decisions (Figure 1).

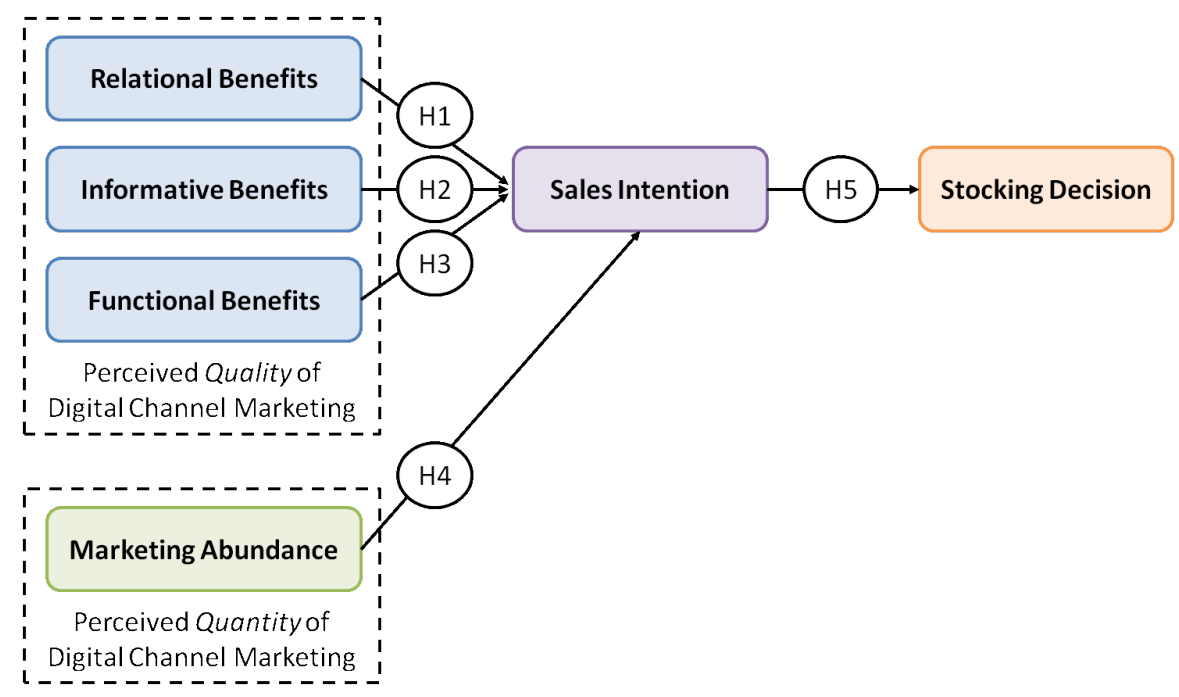

Figure 1. Research model, including the five hypotheses 


\section{Effective Digital Channel Marketing for Cybersecurity Solutions}

\section{Mika Westerlund and Risto Rajala}

\section{Methodology}

We conducted an online survey in late 2008 among Finnish retailers of an internationally operating supplier of cybersecurity products. The company provides a broad range of data security, cybersecurity, and infrastructure security solutions to value-added resellers in 15 countries in Europe and North America. To select the target companies for the survey, we administered it to the active resellers of the supplier's products. Our contact at the company sent an invitation to participate in the survey to 335 potential respondents by email. The questionnaire yielded 109 usable responses, thus giving a response rate of 32.5 percent. We measured all items on a five-point Likert scale ( $1=$ "strongly disagree" to $5=$ "strongly agree).

We chose the Partial Least Squares (PLS) path-modelling method for our empirical analysis. The advantages of PLS include the ability to model multiple constructs, to explore the relative importance of the independent variables, and the ability to handle their multicollinearity. In addition, the method provides us with robustness in the face of missing data; it poses minimum requirements on measurement levels and allows the creation of independent latent variables directly on the basis of cross-products involving the response variables (Chin et al., 2003; Tenenhaus et al., 2005). These concerns are important in our research setting, where there is no strong theory to test in order to explain the phenomenon. In practice, PLS helps to avoid biased and inconsistent parameter estimates for equations, which is appropriate when the research model is in an early stage of development (Teo et al., 2003). We performed the empirical analysis using the SmartPLS 2.0 software by Ringle Wende, and Will (2005).

\section{Results}

The results of our hypothesis testing show that H1, H3, and $\mathrm{H} 5$ are supported, whereas $\mathrm{H} 2$ and $\mathrm{H} 4$ are not supported. In other words, the results suggest that relational benefits $(\mathrm{H} 1 ; \beta=.26, \mathrm{p}<.05)$ and functional benefits $(\mathrm{H} 3 ; \beta=.60, \mathrm{p}<.001)$ of a cybersecurity suppliers' digital channel marketing are positively linked with the increased sales intention of the value-added resellers. Moreover, this sales intention (H5; $\beta=.42, \mathrm{p}<.001$ ) is positively linked with the reseller's actual stocking behaviour. On the contrary, informative benefits (H2; $\beta=-.09$, n.s.) and the quantity of marketing in terms of abundant marketing messages (H4; $\beta=.08$, n.s.) are not linked with the increased sales intension of the valueadded resellers. Table 1 presents the results of hypothesis testing, and Appendix 1 discusses the details of our analysis.

Every analysis has limitations, which provide opportunities for future research. First, we discussed the quality of digital channel marketing in terms of relational, informative, and functional benefits. An in-depth review of marketing communication theory may reveal other aspects, practices, or occasions that can affect the results. Further analysis could also reveal possible differences between new and established relationships between supplies and value-added resellers regarding the impact of supplier's digital channel marketing on the behavioural sales intention of resellers (cf. Andersen, 2001). Second, because our study was conducted in one European country only and focused on cybersecurity as a specific form of complex technology, future research may test our findings in other countries or market areas and in other domains beyond cybersecurity. Third, the results may be different if the effective-

Table 1. Results of hypotheses testing ( $\mathrm{n}=109$, bootstrap samples=1000, $\mathrm{df}=115$ )

\begin{tabular}{clcccc}
\hline Hypothesis & Relationship & $\boldsymbol{\beta}$ & $\boldsymbol{t}$-value & $\boldsymbol{p}$-value & Support \\
\hline H1 & RELATIONAL $\rightarrow$ SALES INTENTION & .26 & 2.70 & .008 & Yes \\
\hline H2 & INFORMATIVE $\rightarrow$ SALES INTENTION & -.09 & 1.30 & .197 & No \\
\hline H3 & FUNCTIONAL $\rightarrow$ SALES INTENTION & .60 & 6.87 & .000 & Yes \\
\hline H4 & ABUNDANT $\rightarrow$ SALES INTENTION & .08 & .90 & .370 & No \\
\hline H5 & SALES INTENTION $\rightarrow$ STOCK & .42 & 3.96 & .000 & Yes \\
\hline
\end{tabular}




\title{
Effective Digital Channel Marketing for Cybersecurity Solutions
}

\author{
Mika Westerlund and Risto Rajala
}

ness of the supplier's digital channel marketing is measured using other variables. Our analysis measured the stocking behaviour of value-added resellers in terms of subjective self-assessment. The behaviour should also be studied using objective financial and non-financial outcomes, such as actual sales figures, purchase frequency, or stocking volume. Thus, we call for empirical research on other variables that could explain a greater variety of reseller behaviour. It would be particularly interesting to examine if the simultaneous use of multiple marketing channels affected a reseller's behavioural sales intention and stocking behaviour.

\section{Conclusion}

The results of this study showed that two types of benefits determine the effectiveness of a cybersecurity supplier's digital channel marketing: relational and functional. The former refers to the perceived improvements in the quality of the relationship between suppliers and value-added resellers, and the latter refers to concrete tools and skills that the supplier can provide to the resellers. Conversely, the informativeness of communication, measured in terms of timely information about new offerings, upgrades, sales campaigns, and promotional offers does not increase the reseller's intention to sell the supplier's cybersecurity solutions. This finding is somewhat surprising, given that suppliers of IT products worldwide put a lot of effort into informing their resellers about price discounts and promotional campaigns. We believe that, because cybersecurity products are characteristically complex and difficult to comprehend by nature, price offers, campaigns, or even new product features are of little interest to value-added resellers. Rather, the resellers need to understand these solutions to be able to sell them at the first place. Cyber-threats are immense and beyond the control of the end customers, who are profoundly dependent on the knowledge of retailers who are selling cybersecurity solutions. In turn, these retailers become dependent on the supplier's technological and domain-specific expertise. Thus, we believe that cybersecurity solution providers, or providers of other complex technologies, who can assist their retailers to create clarity in technological complexity, will eventually gain respect and preferential status among the resellers.

Furthermore, the abundance of supplier's digital channel marketing does not seem to increase intention of value-added resellers to sell the supplier's cybersecurity products. It is likely that the ever-increasing complexity of cybersecurity solutions cause increased informational and cognitive demands for sales professionals, and the abundance of information per se - particularly related to provisional special pricing - does not alleviate their sales burdens. Again, value-added resellers are keen for practical sales tools that will improve their capability to understand and sell these solutions to end customers. Such tools may prove the most effective way of keeping the supplier's cybersecurity product and service brands at the forefront of the reseller's minds. In other words, we found that the marketing effectiveness of cybersecurity providers' digital channel marketing is contingent on the perceived quality rather than the quantity of digital channel marketing. These findings are important for cybersecurity providers, because the perceived quality of digital channel marketing has a direct influence on the intentions of value-added resellers to sell the supplier's cybersecurity products, which ultimately leads to stocking decisions. In addition, the findings support previous findings by, for example, Andersen (2001), who found that marketing communication is connected with relationship development, and a receiver's commitment to the sender is preceded by awareness and persuasion. The findings also support the work of Kauppila and colleagues (2010), who argue that social support from developers improves a salesperson's motivation and decreases their reluctance to sell new technology. Hence, our contribution to theory is that the extent to which digital channel marketing can strengthen the relationship between supplier and value-added reseller and improve the reseller's capabilities to sell cybersecurity solutions to end customers will ultimately determine the effectiveness of channel marketing.

The study offers some practical implications for cybersecurity solution providers, especially for those wishing to benefit from the growing market for cybersecurity products among small and midsized businesses. First, providers should leverage the power of resellers to better reach the fragmented market. However, they have to plan their marketing strategy appropriately. That is, instead of focusing on aggressive price discounts, promotional campaigns, and updates on new features and versions, cybersecurity providers should focus on helping their resellers to understand, communicate, and deliver the value of their cybersecurity solutions to the end customers in the first place. Also, they should pay attention to the quality of interaction with their valueadded resellers, because it has the potential to strengthen or weaken supplier-reseller relationships. In particular, a supplier's digital channel marketing 


\section{Effective Digital Channel Marketing for Cybersecurity Solutions}

\section{Mika Westerlund and Risto Rajala}

should focus on building reciprocal trust and commitment that would result in closer and deeper relationships. Second, cybersecurity suppliers should use digital channel marketing to provide their resellers with concrete sales tools and skills. Value-added resellers commit to sell a cybersecurity solution only if they are able to understand the solution and its value to end customers. The essence of digital channel marketing is to decrease technology and exchange uncertainty and to strengthen collaboration and commitment between suppliers and resellers for improved sales performance.

\section{About the Authors}

Mika Westerlund, D. Sc. (Econ.), is an Assistant Professor at Carleton University's Sprott School of Business in Ottawa, Canada. He previously held positions as a Postdoctoral Scholar in the Haas School of Business at the University of California Berkeley, in the United States, and in the School of Economics at Aalto University in Helsinki, Finland. Mika earned his first doctoral degree in Marketing from the Helsinki School of Economics in Finland. $\mathrm{He}$ is also a $\mathrm{PhD}$ student at Aalto University in the Department of Industrial Engineering and Management. His current research interests include user innovation, industrial ecology, business strategy, and management models in high-tech and service-intensive industries.

Risto Rajala, D.Sc. (Econ), is an Assistant Professor in the Department of Industrial Engineering and Management at Aalto University in Helsinki, Finland. Dr. Rajala holds a PhD in Information Systems Science from the Aalto University School of Business. His recent research concerns the management of complex service systems, development of digital services, service innovation, and business model performance. Rajala's specialties include management of industrial services, collaborative service innovation, knowledge management, and design of digital services.

\section{References}

Ajzen, I. 1985. From Intentions to Actions: A Theory of Planned Behavior. In J. Kuhl \& J. Beckmann (Eds.), Action Control: From Cognition to Behavior. New York: Springer-Verlag.

Andersen, P. H. 2001. Relationship Development and Marketing Communication: An Integrative Model. Journal of Business \& Industrial Marketing, 16(3):167-182.

http://dx.doi.org/10.1108/08858620110389786

Barry, J., \& Terry, T. S. 2008. Empirical Study of Relationship Value in Industrial Services. Journal of Business \& Industrial Marketing, 23(4): 228-241.

http://dx.doi.org/10.1108/08858620810865807

Bentler, P. M., \& Chou, C.-P. 1987. Practical Issues in Structural Modeling. Sociological Methods and Research, 16(1): 78-117. http://dx.doi.org/10.1177/0049124187016001004

Chin, W. W., Marcolin, B. L., \& Newsted, P. R. 2003. A Partial Least Squares Latent Variable Modeling Approach for Measuring Interaction Effects: Results from a Monte Carlo Simulation Study and an Electronic-Mail Emotion/Adoption Study. Information Systems Research, 14(2): 189-217.

http://dx.doi.org/10.1287/isre.14.2.189.16018

Chung, C., Chatterjee, S. C., \& Sengupta, S. 2012. Manufacturers' Reliance on Channel Intermediaries: Value Drivers in the Presence of a Direct Web Channel. Industrial Marketing Management, 41(1): 40-53.

http://dx.doi.org/10.1016/j.indmarman.2011.11.010

Corsaro, D., \& Snehota, I. 2010. Searching for Relationship Value in Business Markets: Are We Missing Something? Industrial Marketing Management, 39(6): 986-995.

http://dx.doi.org/10.1016/j.indmarman.2010.06.018

Craigen, D., Diakun-Thibault, N., \& Purse, R. 2014. Defining Cybersecurity. Technology Innovation Management Review, 4(10): $13-21$.

http://timreview.ca/article/835

Danaher, P. J., \& Rossiter, J. R. 2011. Comparing Perceptions of Marketing Communication Channels. European Journal of Marketing, 45(1/2): 6-42.

http://dx.doi.org/10.1108/03090561111095586

Diamantopoulos, A., \& Siguaw, J. 2000. Introducing Lisrel: A Guide for the Uninitiated. London: SAGE.

Edwards, T., Battisti, G., \& Neely, A. 2004. Value Creation and the UK Economy: A Review of Strategic Options. International Journal of Management Reviews, 5(3-4): 191-213.

http://dx.doi.org/10.1111/j.1460-8545.2004.00103.x

Eggert, A., Ulaga, W., \& Schultz, F. 2006. Value Creation in the Relationship Life Cycle: A Quasi-Longitudinal Analysis. Industrial Marketing Management, 35(1): 20-27. http://dx.doi.org/10.1016/j.indmarman.2005.07.003

Fishbein, M. \& Ajzen, I. 1975. Belief, Attitude, Intention, and Behavior: An Introduction to Theory and Research. Reading, MA: AddisonWesley.

Fornell, C., \& Larcker, D. F. 1981. Evaluating Structural Equation Models with Unobservable Variables and Measurement Error. Journal of Marketing Research, 18(1): 39-50.

http://www.jstor.org/stable/3151312 


\section{Effective Digital Channel Marketing for Cybersecurity Solutions}

\section{Mika Westerlund and Risto Rajala}

Hansen, H., Samuelsen, B. M., \& Silseth, P. R. 2008. Customer Perceived Value in B-to-B Service Relationships: Investigating the Importance of Corporate Reputation. Industrial Marketing Management, 37(2): 206-217. http://dx.doi.org/10.1016/j.indmarman.2006.09.001

Holden-Bache, A. 2011. Study: 93\% of B2B Marketers Use Social Media Marketing. Social Media B2B. October 1, 2014: http://socialmediab2b.com/2011/04/93-of-b2b-marketers-usesocial-media-marketing/

Hughes, D. E., \& Ahearne, M. 2010. Energizing the Reseller's Sales Force: The Power of Brand Identification. Journal of Marketing, 74(4): 81-96. http://dx.doi.org/10.1509/jmkg.74.4.81

Hughes, D.E. 2013. This Ad's for You: The Indirect Effect of Advertising Perceptions on Salesperson Effort and Performance. Journal of the Academy of Marketing Science, 41(1): 1-18. http://dx.doi.org/10.1007/s11747-011-0293-y

Jerman, D., \& Zavrsnik, B. 2012. Model of Marketing Communications Effectiveness in the Business-to-Business Markets. Economic Research - Ekonomska Istrazivanja, 25(1): 364-388.

Johanson, D. 2013. The Evolving U.S. Cybersecurity Doctrine. Security Index: A Russian Journal on International Security, 19(4): 37-50. http://dx.doi.org/10.1080/19934270.2013.846072

Kalyanam, K., \& Brar, S. 2009. From Volume to Value: Managing the Value-Add Reseller Channel at Cisco Systems. California Management Review, 52(1): 94-119. http://www.jstor.org/stable/10.1525/cmr.2009.52.1.94

Kumar, N., Stern, L. W., \& Achrol, R. S. 1992. Assessing Reseller Performance From the Perspective of the Supplier. Journal of Marketing Research, 29(2): 238-253.

http://www.jstor.org/stable/3172573

Lemmink, J., de Ruyter, K., \& Wetzels, M. 1998. The Role of Value in the Delivery Process of Hospitality Services. Journal of Economic Psychology, 19(2): 159-177. http://dx.doi.og/10.1016/S0167-4870(98)00002-6

Lilien, G. L., Grewal, R., Bowman, D., Ding, M., Griffin, A., Kumar, V., Narayandas, D., Peres, R., Srinivasan, R., \& Wang, Q. 2010. Calculating, Creating, and Claiming Value in Business Markets: Status and Research Agenda. Marketing Letters, 21(3): 287-299. http://dx.doi.org/10.1007/s11002-010-9108-z

Lindgreen, A., \& Wynstra, F. 2005. Value in Business Markets: What Do We Know? Where Are We Going? Industrial Marketing Management, 34(7): 732-748. http://dx.doi.org/10.1016/j.indmarman.2005.01.001

Lindgreen, A., Palmer, R., Vanhamme, J., \& Wouters, J. 2006. A Relationship-Management Assessment Tool: Questioning, Identifying, and Prioritizing Critical Aspects of Customer Relationships. Industrial Marketing Management, 35(1): 57-71. http://dx.doi.org/10.1016/j.indmarman.2005.08.008

Menon, A., Homburg, C., \& Beutin, N. 2005. Understanding Customer Value in Business-to-Business Relationships. Journal of Businessto-Business Marketing, 12(2): 1-38. http://dx.doi.org/10.1300/J033v12n02_01

Mohr, J., \& Spekman, R. 1994. Characteristics of Partnership Success: Partnership Attributes, Communication Behavior, and Conflict Resolution Techniques. Strategic Management Journal, 15(2): 13552.

http://dx.doi.org/10.1002/smj.4250150205
Payne, A., \& Holt, S. 2001. Diagnosing Customer Value: Integrating the Value Process and Relationship Marketing. British Journal of Management, 12(2): 159-182. http://dx.doi.org/10.1111/1467-8551.00192

Rahmani, Z., Mojaveri, H.S., \& Allahbakhsh, A. 2012. Review the Impact of Advertising and Sale Promotion on Brand Equity. Journal of Business Studies Quarterly, 4(1): 64-73.

Rapp, A., Beitelspacher, L. S., Grewal, D., \& Hughes, D. E. 2013. Understanding Social Media Effects Across Seller, Retailer, and Consumer Interactions. Journal of the Academy of Marketing Science, 41(5): 547-566.

http://dx.doi.org/10.1007/s11747-013-0326-9

Ringle, C. M., Wende, S., \& Will, S. 2005. SmartPLS 2.0 (M3) Beta, Hamburg.

http://www.smartpls.de

Simpson, P. M., Siguaw, J. A., \& Baker, T. L. 2001. A Model of Value Creation - Supplier Behaviors and Their Impact on ResellerPerceived Value. Industrial Marketing Management, 30(2): 119134.

http://dx.doi.org/10.1016/S0019-8501(00)00138-3

Sreenivas, M., \& Srinivas, T. 2008. Effectiveness of Distribution Network. International Journal of Information Systems and Supply Chain Management, 1(1): 80-86. http://dx.doi.org/10.4018/jisscm.2008010105

Tenenhaus, M., Vinzi, V. E., Chatelin, Y.-M., \& Lauro, C. 2005. PLS path modeling. Computational Statistics and Data Analysis, 48(1): 159-205. http://dx.doi.org/10.1016/j.csda.2004.03.005

Teo, H. H., Kwok, K. W., \& Benbasat, I. 2003. Predicting Intention to Adopt Interorganizational Linkages: An Institutional Perspective. MIS Quarterly, 27(1): 19-49. http://www.jstor.org/stable/30036518

The 2112 Group. 2014. The Power of Multiples: Best Practices for Selling Best-of-Breed Solutions. Port Washington, NY: The 2112 Group.

Ulaga, W. 2003. Capturing Value Creation in Business Relationships: A Customer Perspective. Industrial Marketing Management, 32(8): 677-693.

http://dx.doi.org/10.1016/j.indmarman.2003.06.008

Walters, D., \& Lancaster, G. 2000. Implementing Value Strategy through the Value Chain. Management Decision, 38(3):160-178. http://dx.doi.org/10.1108/EUM0000000005344

Webster, F. E., Jr. 2000. Understanding the Relationships among Brands, Consumers, and Resellers. Journal of the Academy of Marketing Science, 28(1): 17-23. http://dx.doi.org/10.1177/0092070300281002

Villarejo-Ramos, A. F. 2005. The Impact of Marketing Communication and Price Promotion on Brand Equity. Journal of Brand Management, 2(6): 431-444. http://dx.doi.org/10.1057/palgrave.bm.2540238

Wold, H. 1982. Systems under Indirect Observation Using PLS. In: C. Fornell (Ed.), A Second Generation of Multivariate Analysis: 325347. Praeger, New York. 


\section{Effective Digital Channel Marketing for Cybersecurity Solutions}

\section{Mika Westerlund and Risto Rajala}

\section{Appendix 1. About the Research}

We applied the partial least squares (PLS) method of analysis suggested by Wold (1982) to estimate the parameters. First, we ensured that our data of 109 companies and 15 indicators meets the guideline of five or more respondents per indicator (cf. Bentler and Chou, 1987). Second, we examined composite reliability values ( $\rho c)$ and average variance extracted values ( $\rho$ v) for each latent variable to assess the reliability and validity of the constructs. The scales seem to perform amply: $\rho c$ exceeded the recommended minimum level of .70 (cf. Fornell and Larcker, 1981) and $\rho \mathrm{v}$ exceeded the .50 benchmark (cf. Diamantopoulos and Siguaw, 2000). Table 2 shows these values as well as means, standard deviations, and correlations for the constructs.

We examined the correlation matrix of the constructs in order to assess discriminant validity. Fornell and Larcker (1981) put forward that satisfactory discriminant validity among constructs is obtained when the square root of the average variance extracted is greater than corres- ponding construct correlations. In our data, the square root of the average variance extracted exceeded their correlations for each pair of first-order constructs (see numbers in parentheses in Table 1). All constructs met the criterion, which supports the discriminant validity of the constructs. The scale items used in the survey, as well as constructs and are listed in Table 3.

The PLS path modelling approach does not include proper single goodness of fit measure, but we used the global fit measure (GoF) suggested by Tenenhaus and colleagues (2005) to evaluate the goodness of fit in our model. Given that the criteria for small, medium, and large effect sizes are .10, .25, and .36, the GoF of our model (.46) indicates a good fit to the data. Furthermore, we assessed the explanatory power of the model for the dependent constructs by measuring their squared multiple correlations value $\left(\mathrm{R}^{2}\right)$. The independent variables were able to explain 62.3 percent of the variation in reseller's behavioural sales intention and 17.2 percent of the resulting stocking decision, both of which are considered appropriate.

Table 2. Construct correlations and descriptive statistics of measures

\begin{tabular}{|c|c|c|c|c|c|c|c|c|c|c|}
\hline Construct & Mean & SD & $\rho_{\mathbf{v}}$ & $\rho_{c}$ & 1 & 2 & 3 & 4 & 5 & 6 \\
\hline 1. Functional benefits & 3.15 & 1.07 & .86 & .93 & $(.93)$ & & & & & \\
\hline 2. Informative benefits & 3.69 & 0.83 & .71 & .88 & .51 & $(.84)$ & & & & \\
\hline 3. Stocking decision & 1.94 & 0.91 & .85 & .92 & .35 & .12 & $(.92)$ & & & \\
\hline 4. Relational benefits & 2.80 & 0.92 & .84 & .94 & .60 & .58 & .23 & $(.92)$ & & \\
\hline 5. Sales intention & 2.64 & 0.98 & .83 & .91 & .75 & .42 & .41 & .63 & $(.91)$ & \\
\hline 6. Marketing abundance & 2.39 & 0.76 & .67 & .86 & .46 & .59 & .22 & .72 & .49 & $(.82)$ \\
\hline
\end{tabular}

Citation: Westerlund, M., \& Rajala, R. 2014. Effective Digital Channel Marketing for Cybersecurity Solutions. Technology Innovation

Management Review, 4(10): 22-32. http://timreview.ca/article/836 


\section{Effective Digital Channel Marketing for Cybersecurity Solutions}

\section{Mika Westerlund and Risto Rajala}

Table 3. Scale items and constructs

\section{Quality of Digital Channel Marketing}

\begin{tabular}{|c|c|c|c|}
\hline \multicolumn{3}{|c|}{ RELATIONAL BENEFITS } & $\begin{array}{l}\text { Modified from Walters \& Lancaster (2000); Andersen (2001); Corsaro \& Snehota (2010); Eggert } \\
\text { et al. (2006). }\end{array}$ \\
\hline $\mathrm{K} 12$ & .89 & .35 & $\begin{array}{l}\text { Supplier's digital channel marketing (DCM) improves collaboration in our supplier-reseller } \\
\text { relationship. }\end{array}$ \\
\hline $\mathrm{K} 14$ & .94 & .38 & Supplier's DCM augments long-lasting and close relationship with us \\
\hline \multicolumn{3}{|c|}{ INFORMATIVE BENEFITS } & Modified from Martin et al. (2003); Villarejo-Ramos (2005); Eggert et al. (2006). \\
\hline K7 & .92 & .53 & Receiving ongoing sales campaigns and promotional offers is important \\
\hline \multicolumn{3}{|c|}{ FUNCTIONAL BENEFITS } & Modified from Lindgreen et al. (2006). \\
\hline $\mathrm{K} 17$ & .93 & .56 & Supplier's DCM improves our sales skills and capabilities \\
\hline K18 & .92 & .52 & Supplier's DCM provides us with practical sales tools \\
\hline
\end{tabular}

\section{Quantity of Digital Channel Marketing}

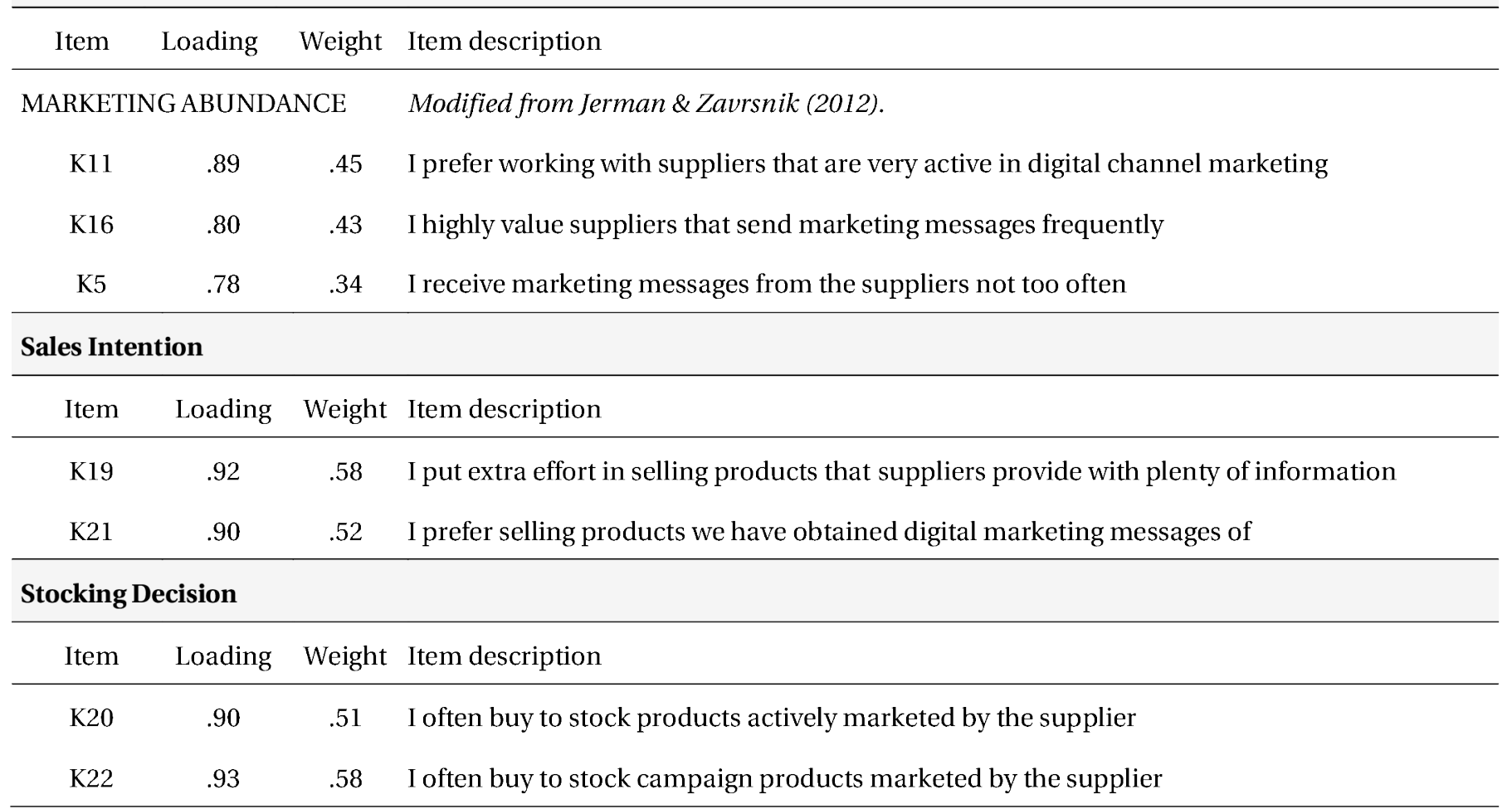

